\title{
KŘESŤANÉ PŘED VOLBOU: STÁT SE MUSLIMEM, NEBO ZEMŘÍT? K OTÁZCE KONVERZÍ K ISLÁMU BĚHEM ARMÉNSKÉ GENOCIDY
}

M ICHAL ̌̌ OUTIL

\section{ABSTRACT \\ Christians in front of a Choice: Become a Muslim or Die? On the Question of Conversions to Islam during the Armenian Genocide}

This article focuses on the issue of Christian conversions (forced or voluntary) to Islam during the Armenian genocide. The essay examines the ideology of turkification that was behind these efforts, including Ottoman government-sponsored orphanages as a direct means of assimilating Armenian children. It pays particular attention to the process of 'rebuilding' the Armenian nation in the immediate aftermath of World War I sometimes called 'national reconstruction'. In the final part the paper deals with the phenomenon of the 'Hidden Armenians' in contemporary Turkey.

\section{Keywords}

Armenians; Genocide; Conversion; Islamisation; Ottoman Empire

DOI: $10.14712 / 23363398.2018 .14$

[Moje matka mi řekla:] „Musíš se vzdát své víry... podváděj, lži, napodobuj, předstírej - hlavně se snaž přežít, než se ta bouře přežene. Podívej se okolo sebe: žádný chlapec v tvém věku již nežije““

„Ale co bude s vámi, manželkami mých bratrů a dětmi?“ zeptal jsem se. „Neboj se, nijak nám tady nepomůžeš... a když nás Pán volá,“ odpověděla a pokřižovala se, „musíme zemřít důstojně a věrni své víře.“1

1 Úryvek z románových vzpomínek arménského spisovatele Arama Haigaze (vl. jménem Aram Čekenian, 1900-1986), který byl jako patnáctiletý mladík očitým svědkem povstání křestanů ve městě Şebinkarahisar v červnu 1915; po jeho dobytí Turci většinu mužské populace pobili a zbytek donutili odejít z města v konvojích smrti. Scéna 
V průběhu dějin Osmanské říše docházelo ke konverzím místních křestanů (Arménů, Řeků, Asyřanů, Srbů, Bulharů, Vlachů, Rumunů, Arabů a dalších etnik) k islámu v zásadě ze dvou popudů - dobrovolně a násilím. Systém milletů, tedy vnitřní uspořádání říše na základě nábožensko-etnického klíče, konverze nepodporoval, jeho účel spočíval v náboženském, politickém a společenském smíru. ${ }^{2}$ Za jistých okolností ovšem sultán či armáda konverzi vyžadovali, jednalo se např. o janičáry, sultánovo elitní vojsko rekrutované z mladých křestanských chlapců (zprvu většinou z pravoslavných věřících Balkánu, poté $\mathrm{z}$ anatolských křestanů), u nichž byl přechod k islámu důsledně vyžadován. ${ }^{3}$ Později, za vlády sultána Abdülhamida II. (1876-1909), stát podnikl v rámci „osmanizace“ obyvatelstva několik kampaní zaměřených na islamizaci etnicko-náboženských společenství stojících mimo oficiální sunnitský islám - například na beduíny, považované pouze za „nominální muslimy“, či na „heretické sektáře“, tedy kurdské jezídy z pohoří Sindžár. ${ }^{4}$

Osmanští Arméni někdy přecházeli k islámu dobrovolně, a to především kvůli sociálnímu vzestupu či z ekonomických důvodů. Těchto konverzí ovšem nikdy nebylo mnoho a týkaly se spíše vyšších pater společnosti ve městech. Arménská komunita pak tyto jednotlivce nejednou považovala za „zrádce“, „odpadlíky“ a „Nearmény“. Osmanské úřady ovšem často nemusely konverzi vyžadovat - mnoho křestanských Arménů udělalo kariéru př́mo na sultánově dvoře, mj. sloužili jako osobní lékaři či bankéři samotného sultána. ${ }^{5}$

se odehrává ve vesnici Aghvanis (v okrese Suşehir, provincie Sivas), kdy již konvoj putoval několik dní a bylo zřejmé, že většina nepřežije, a jediná záchrana spočívala v přijetí islámu; viz: Aram Haigaz. Four Years in the Mountains of Kurdistan, 19151919. An Armenian Boy's Memoir of Survival. Bronxville, NY: Maiden Lane Press 2014, s. 26.

2 Viz nejnověji: Stefano Taglia. Náboženství v Osmanské říši. In: Jiří Gebelt et al. Ve stínu islámu. Menšinová náboženství na Blizkém východě. Praha: Vyšehrad 2016, s. 41-45; Benjamin Braude. Foundation Myths of Millet System. In: Benjamin Braude - Bernard Lewis (eds.). Christians and Jews in the Ottoman Empire. The Functioning of a Plural Society. Sv. 1. The Central Lands. New York - London: Holmes \& Meier Publishing 1982, s. 69-88; Maurits H. van den Boogert. Millets: Past and Present. In: Anne Sofie Roald - Anh Nga Longva (eds.). Religious Minorities in the Middle East: Domination, Self-Empowerment, Accommodation. Leiden: Brill 2011, s. 27-45 aj.

3 Více k podobám přechodů k jinému náboženství od reforem Tanzimât (konec 30. let 19. století) viz: Selim Deringil. Conversion and Apostasy in the Late Ottoman Empire. Cambridge: Cambridge University Press 2012, s. 28nn.

4 Selim Deringil. The Well-Protected Domains: Ideology and the Legitimation of Power in the Ottoman Empire, 1876-1909. London - New York: I. B. Tauris 2009², s. 68nn.

5 Obdobná situace platila i pro osmanské Řeky. 
Jiná situace nastala $\mathrm{v}$ dobách, kdy propukalo bud' státem řízené, nebo tolerované násilí na křestanech. Během masakrů křestanů, k nimž došlo mj. v červenci 1860 v Damašku (přibližně 10 tisíc obětí), v letech 1894-1896 (tzv. hamídíjské masakry, 200 až 300 tisíc obětí) po celém území ŕíše a v dubnu 1909 ve městě Adana (25 až 30 tisíc obětí), znamenala konverze často jediný způsob, jak se vyhnout jisté smrti. Zvláště během hamídíjských masakrů již křestané (pogrom postihl také Asyřany) užívali všech možných způsobů, jak se vyhnout pronásledování - včetně konverzí. Tak jako během genocidy museli nejednou horlivě obhajovat své rozhodnutí přijmout islám - například Arméni z vesnice Köyulhisar v provincii Sivas prohlašovali: „Přijali jsme islám ze svobodné vůle. V našich průkazech totožnosti sice stojí, že jsme Arméni, ve svých srdcích a stylu oblékání však jsme muslimové [...] stát nás může třeba oběsit, pokud bude chtít, jsme k tomu svolní, ale islámu se nevzdáme.“6 Otázkou zůstává, nakolik byly tyto výroky upřímné a zda spíše nepředstavovaly další zoufalý pokus o přesvědčování nepřátelského okolí v autenticitě tohoto postupu.

\section{Arménská genocida - průběh, aktéři a oběti}

Situace Arménů a ostatních křestanů se začala pomalu zhoršovat po vstupu Osmanské říše do 1. světové války v listopadu 1914. Muži ve věku 20-45 let byli odvedeni do osmanské armády, po celé říši pokračoval bojkot křestanského zboží. Po prohrané bitvě u Sarıkamışe (leden 1915) na východě a vylodění Spojenců v Gallipoli (únor téhož roku) začalo vedení země, tj. vládnoucí strana Výbor jednoty a pokroku (İtthat ve Terakki Cemiyeti, též mladoturci), pohlížet na Armény jako na „pátou kolonu“ a potenciálního spojence Ruska. ${ }^{7}$

6 Selim Deringil. The Armenian Question Is Finally Closed: Mass Conversions of Armenians in Anatolia during the Hamidian Massacres of 1895-1897. Comparative Studies in Society and History 51 (2009), s. 355.

7 K arménské genocidě viz nejnověji: Michal Řoutil - Petra Koštálová - Petr Novák. Katastrofa kŕestanů. Likvidace Arménů, Asyřanů a Řeků v Osmanské ŕšsi v letech 1914-1923. Červený Kostelec: Pavel Mervart 2017; a standardní práce: Vahakn N. Dadrian. The History of the Armenian Genocide: Ethnic Conflict from the Balkans to Anatolia to the Caucasus. London - New York: Berghahn Books 1995; Taner Akçam. A Shameful Act: The Armenian Genocide and the Question of Turkish Responsibility. London: Holt McDougal 2007² Raymond H. Kévorkian. The Armenian Genocide. A Complete History. London - New York: I. B. Tauris 2011; Ronald Grigor Suny - Fatma Müge Göçek - Norman Naimark (eds.). A Question of Genocide: Armenians and Turks at the End of the Ottoman Empire. Oxford - New York: Oxford University Press 2011; 
Průběh arménské genocidy lze rozdělit do dvou základních fází: 1) vyvraždění arménské mužské populace a deportace zbylého obyvatelstva (duben - prosinec 1915); 2) vznik tranzitních a koncentračních táborů a likvidace deportovaných (prosinec 1915 - prosinec 1916).

Koncem dubna 1915 nechal ministr vnitra Talât Paşa zatknout a uvěznit přes dvě stě zástupců konstantinopolské arménské elity. O měsíc později předložil kabinetu návrh zákona o přesídlení obyvatelstva a Sněmovna poslanců (Meclis-i Mebusan) jej 27. května přijala; následně zákon signoval velkovezír Said Halim. Tzv. Zákon o deportacích (Sevk ve İskân Kanunu), kvůli němuž musel své domovy opustit více než milion Arménů, vstoupil v platnost 1. června 1915.

Ačkoliv v Zákonu o deportacích nebyli Arméni explicitně zmíněni, právě na ně dopadl nejhůře. Deportace do východosyrské pouště se týkaly nejen šesti východoanatolských vilájetů (provincií), v nichž Arméni především žili (Erzurum, Van, Bitlis, Diyarbekir, Charput/ Mamuret ül-Aziz a Sivas), nýbrž celé země. ${ }^{8}$ Kromě některých míst, kde vláda svěřila deportace do rukou armádních oddílů a místního četnictva, se na jejich organizaci a provedení podílela polotajná Speciální organizace (Teşkilat-ı Mahsûsa). Organizace měla na 30 tisíc členů a spadala pod osmanské ministerstvo války. Právě Speciální organizace a oddíly çete, vytvořené z místních Kurdů, Čerkesů a propuštěných vězňů, měly na svědomí největší počet obětí.

Během deportací (de facto pochodů smrti) byli vyhnaní Arméni - většinou ženy, děti a staří lidé - postupně okradeni o veškerý majetek, ženy a dívky znásilňovány, a poté nejrůznějšími zpo̊soby týrány a vražděny. Na většině deportačních tras dosahovala úmrtnost až 90 procent. Deportace se tak staly prostředkem k vyvraždění většiny národa.

Druhá fáze genocidy probíhala již v tranzitních a koncentračních táborech podél řeky Eufrat (Sebka, Meskene, Abúharár, Hamám, Rakka aj.), ale také poblíž syrských měst, např. Aleppa. Na těchto místech

Taner Akçam. The Young Turks' Crime Against Humanity: The Armenian Genocide and Ethnic Cleansing in the Ottoman Empire. Princeton, New Jersey: Princeton University Press 2012; Raymond H. Kévorkian - Yves Ternon. Mémorial du génocide des Arméniens. Paris: Seuil 2014; Ronald Grigor Suny. "They Can Live in the Desert but Nowhere Else": A History of the Armenian Genocide. Princeton, New Jersey - Oxford: Princeton University Press 2015 aj.

8 Michal Řoutil - Petra Koštálová - Petr Novák. Katastrofa krestanů. Likvidace Arménů, Asyřanů a Řeků v Osmanské ř́ši v letech 1914-1923, s. 140-199; Raymond H. Kévorkian. The Armenian Genocide. A Complete History, s. 285-621. 
došlo postupně k vyvraždění většiny deportovaných osob. Symbolem arménského utrpení se stalo místo zvané Deir ez-Zor (Dajr az-Zaur, Der Zor), v němž našlo smrt na 200 až 300 tisíc Arménů. ${ }^{9}$

Během arménské genocidy přišlo o život 800 tisíc až 1,2 milionu osob. Otázce, zda konvertovat k islámu a pokusit se tak zachránit holý život, byly vystaveny statisíce osob. Výzva k takto masovému opuštění víry zřejmě nemá v dějinách křestanství obdoby.

\section{Nevěřící, obratte se!}

Možnost konvertovat k islámu se Arménům a ostatním křestanům nabízela ihned po začátku pronásledování. Přesněji řečeno, tato alternativa zde existovala i předtím - postupně se z ní ovšem stala otázka života a smrti. Z různých pramenů se dozvídáme, že ochota Arménů konvertovat rostla úměrně zhoršující se situaci. Zpočátku si patrně většina nepřipouštěla, že by mohlo propuknout vyvražd'ování v rozsahu hamídíjských masakrů.

Úředníci prováděli na křestany nátlak i jinými způsoby - instruovali např́iklad horlivé muslimy, aby navštěvovali své křestanské sousedy a přemlouvali je k přijetí islámu. Německý honorární konzul v Samsunu M. Kuckhoff uvádí ve zprávě z 4. července 1915, že se tak dělo $\mathrm{v}$ tomto městě $\mathrm{v}$ masovém měřítku:

Vláda posílá fanatické a nekompromisní muslimy, muže i ženy, do všech arménských domácností, aby tam šírili propagandu za účelem konverze k islámu. Děje se tak samozřejmě pod hrozbou vážných důsledků pro ty, kdo zůstanou pevní ve své víre. ${ }^{10}$

Někdy, jako například ve městě Samsun, křestany přemlouvali ke konverzi i samotní muslimští duchovní (ulamá, muftí, hodžové). ${ }^{11}$ Jiní duchovní naopak zachraňovali Armény a Asyřany před deportace-

9 K Deir ez-Zoru viz více: Michal Řoutil - Petra Koštálová - Petr Novák. Katastrofa křestanů. Likvidace Arménů, Asyřanů a Řeků v Osmanské ř́ši v letech 1914-1923, s. 222-225; Hilmar Kaiser. At the Crossroads of Der Zor: Death, Survival, and Humanitarian Resistance in Aleppo, 1915-1917. Reading: Gomidas Institute 2002.

10 Wolfgang Gust (ed.). Der Völkermord an den Armeniern 1915/16. Dokumente aus dem Politischen Archiv des deutschen Auswärtigen Amts. Springe: Klampen 2005, s. 208.

11 Do některých arménských křestanských rodin dojížděl několikrát týdně muslimský hodža, aby je vzdělal v islámu, viz např. Payladzo Aragel Captanian. Mémoires d'une déportée arménienne. Paris 1919, s. 11-12. 
mi tím, že je zapsali do registrů jako muslimy (často ovšem za finanční náhradu). ${ }^{12}$

Zvláště početné konverze byly zaznamenány v kilíkijské Adaně a ve městech na černomořském pobřeží. Čerství arménští konvertité z Ordu, Samsunu či Fatsy dokonce sepisovali se svými novými náboženskými lídry petice, v nichž prohlašovali, že nejsou ve styku s těmi Armény, kteří jsou „nečistí“ (mülevves) a zrazují svou vlast. ${ }^{13}$

Vlnu konverzí potvrzovala i další hlášení do Berlína - velvyslanec v Konstantinopoli Hans von Wangenheim sděloval 7. července 1915, že „Arméni z Trabzonu houfně konvertují k islámu, aby se vyhnuli deportacím a zachránili si život a majetek“. ${ }^{14}$ Podle amerického misionáře Jesse K. Mardena, jenž v létě 1915 pobýval v Merzifonu (Marsovanu), bylo z tohoto města deportováno z 13 tisíc Arménů 11500 jedinců, ostatní, tedy 1500 osob, přijali islám „jako alternativu jisté smrti“. ${ }^{15}$ Jak takové konverze probíhaly z hlediska organizace, dokládá zpráva učitele z merzifonské Anatolia College ze stejné doby:

Během této nadvlády teroru bylo oznámeno, že každý, kdo přijme islám, bude moci zůstat v bezpečí domova. Právnické kanceláře, které evidovaly žádosti, byly přeplněny lidmi, kteří se chtěli stát muslimy. Mnoho z nich tak činilo kvůli záchraně svých žen a dětí. Mysleli si, že se jedná pouze o otázku několika týdnů, než přijde pomoc. ${ }^{16}$

Odhaduje se, že městské arménské obyvatelstvo v dotčených oblastech konvertovalo zhruba v rozmezí 10 až 20 procent, některé vesnice ovšem přešly k islámu celé. Arménské „muslimské“ obyvatelstvo vláda nebo lokální úředníci obvykle nenechali žít v místě pobytu. Nejčastěji byli vystěhováváni do tradičních muslimských vesnic či městských muslimských čtvrtí.

Telegram zaslaný guvernérem oblasti Canik Necmiem Beyem 9. července 1915 do Konstantinopole popisuje nejen průběh deportací, nýbrž také rozmistování konvertovaných Arménů takto:

\footnotetext{
Yves Ternon. Empire ottoman: Le declin, la chute, l'effacement. Paris: Editions du Félin 2002, s. 94.

13 Michal Řoutil - Petra Koštálová - Petr Novák. Katastrofa křestanů. Likvidace Arménů, Asyřanů a Řeků v Osmanské ŕiši v letech 1914-1923, s. 262-263.

14 Wolfgang Gust (ed.). Der Völkermord an den Armeniern 1915/16, s. 186.

15 Ara Sarafian (ed.). United States official records on the Armenian genocide, 1915-1917.

Princeton, New Jersey - London: Taderon Press 2004, s. 525.

16 Tamtéž, s. 143.
} 
Potvrzujeme, že poslední karavana Arménů odešla ze Samsunu před čtyřmi dny společně se svými náboženskými vůdci [...] tímto způsobem byl proces vyhnání ukončen. Ti, kteří na místě zůstali za účelem dokončení procedur spojených s jejich přihlášením se ke konverzi, budou dle podmínek okamžitě přesunuti do města a vesnic. Tam budou rozmístěni po jednom či dvou mezi muslimské vesnické sousedy. Do jejich [př́íbytků] budou přestěhováni muslimští uprchlíci a migranti. ${ }^{17}$

Přechod k islámu někdy Armény skutečně uchránil deportací, byt většinou pouze dočasně. Hlášení německého velvyslance Wolff-Metternicha z 24. ledna 1916 dosvědčuje, že je ani tento zásadní krok nedokázal ochránit: „Všude tam, kde se masy Arménů rozhodly z vlastní vůle konvertovat k islámu, aby se vyhnuly vyhnání a konfiskaci majetku, jim vláda za toto gesto neposkytuje žádné výhody a deportovala je nehledě na jejich konverzi.“18

Mladoturecké vedení si záhy po začátku protiarménské kampaně uvědomilo, že masové konverze mohou narušit prủběh deportací a způsobit, že mnoho Arménů zůstane v Anatolii, i když nyní již jako „muslimové“. K 1. červenci 1915 tak přišel z centra př́kaz zakazující přechod křestanů k islámu, čímž pro Armény odpadla poslední možnost záchrany. Ministr vnitra Talât, jenž někdy osobně povoloval či zamítal konverze vlivných Arménů v provinciích, měl o účelu přechodů k islámu jasno: „Někteří z vysídlovaných Arménů se zavazují, že masově nebo individuálně konvertují, a tímto zpo̊sobem si chtějí zajistit, aby zůstali na rodné půdě [...] k těmto žádostem se nelze v žádném případě stavět kladně." ${ }^{19}$

Ne všude se však příkazy plnily se stejnou horlivostí. Úředníci ve východoanatolských provinciích přivykli vlažnému přístupu k úkolům z centra a dávali často přednost vlastním zájmům. Bohatší Arméni tak i nadále mohli někdy díky korupci prosadit svou žádost o přechod k islámu, čímž dočasně odvrátili hrozbu okamžité deportace. Tento postup však neušel agentům Speciální organizace, kteří o něm okamžitě podali zprávu vládě. Další tajný telegram již hovořil zcela jasnou řečí:

Taner Akçam. The Young Turks' Crime Against Humanity: The Armenian Genocide and Ethnic Cleansing in the Ottoman Empire, s. 295.

18 Wolfgang Gust (ed.). Der Völkermord an den Armeniern 1915/16, s. 424.

19 Taner Akçam. The Young Turks' Crime Against Humanity: The Armenian Genocide and Ethnic Cleansing in the Ottoman Empire, s. 295-296. 
[...] jak již bylo dříve sděleno v telegramu z 1. července 1915: pokud jde o typy konverzí, k nimž dochází výhradně z osobního zájmu, nemají tyto žádné oficiální svolení, takže umožňovat výjimky v nakládání s konvertity je absolutně nepř́pustné. $V$ obecném souladu s ostatními direktivami v předchozí komunikaci se proto vyžaduje nepřikládat těmto neupřímným a dočasným konverzím žádnou zvláštní důležitost... ${ }^{20}$

Nehledě na jednoznačné znění příkazů muselo místy k přechodům k islámu docházet i nadále, o čemž svědčí několik dalších telegramů podobného obsahu zaslaných místním guvernérům.

Konverze k islámu vláda opět povolila až ke konci roku 1915. Okamžitě se této možnosti snažily využít zbytky nedeportovaných Arménů - podle německého generálního konzula v Konstantinopoli Johanna H. Mordtmanna se tak dělo mj. v Trabzonu, Adaně a Konyi. ${ }^{21}$ Nešlo však o masové akce - tou dobou již byla značná část Arménů z východní Anatolie a severní Mezopotámie povražděna a ostatní čekali na smrt v tranzitních a koncentračních táborech severovýchodní Sýrie. ${ }^{22}$ Takřka beze zbytku se tím naplnilo polotajné „pravidlo 5 až 10 procent“ - tedy budoucí nejvyšší tolerovatelná kvóta křestanů v rámci muslimské většiny, jehož realizace začala již v roce 1913 a týkala se rovněž Řeků a Asyřanů. ${ }^{23}$ Ruku v ruce s islamizací pozůstatku křestanského osídlení šla jejich asimilace s muslimským prostředím.

Během arménské genocidy docházelo $\mathrm{v}$ zásadě k pěti typům konverzí k islámu:

1) „dobrovolné“ konverze jednotlivců před deportacemi a na jejich začátku;

2) případy, kdy si konkrétní muslimské rodiny vybíraly mezi deportovanými jednotlivce a tito pak museli změnit víru;

3) státem řízené umistování Arménů do muslimských domácností a jejich poturčení;

\footnotetext{
Tamtéž, s. 296-297.

Wolfgang Gust (ed.). Der Völkermord an den Armeniern 1915/16, s. 402-403.

22 Taner Akçam. The Young Turks' Crime Against Humanity: The Armenian Genocide and Ethnic Cleansing in the Ottoman Empire, s. 291.

23 Tamtéž, s. 242-248; Michal Řoutil - Petra Koštálová - Petr Novák. Katastrofa křestanů. Likvidace Arménů, Asyřanů a Řeků v Osmanské ŕíši v letech 1914-1923, s. 212-213.
} 
4) nucené konverze arménských sirotků ve státem zřizovaných sirotčincích;

5) kolektivní konverze. ${ }^{24}$

\section{Islamizace jako prostředek poturčení}

Mladoturecké vedení země - ministr vnitra Talât, ministr války Enver a ministr námořnictva Cemal - užívalo islamizace zcela účelově. Jako sekulární zastánci národního státu - v konturách evropského chápání tohoto pojmu -, který chtěli z Osmanské říše vytvořit, tímto vycházeli vstříc některým vrstvám společnosti, zejména konzervativním náboženským kruhům. Oporu našli v nově se rodícím tureckém nacionalismu, jenž na intelektuální úrovni reprezentoval např́íklad sociolog Mehmet Ziya Gökalp (1876-1924), či v panturkismu, za jehož čelné představitele lze považovat Yusufa Akçuru (1876-1935) a Moize Cohena (Munis Tekinalp, 1883-1961).

Islamizačních snah si všímali také zahraniční rezidenti. Německý velvyslanec v Konstantinopoli Hans von Wangenheim poslal v hlášení z 16. července 1915 do Berlína kancléři Bethmann-Hollwegovi př́lohu, v níž honorární konzul M. Kuckhoff popisoval mladoturecké záměry:

Současné vedení země je pevně rozhodnuto islamizovat Turecko a použije k tomu veškeré prostředky, které má. Vůbec je nezajímá, jaké obrovské ztráty přinese státu, stejně jako lokálnímu a zahraničnímu obchodu likvidace arménského živlu. ${ }^{25}$

Ve zprávě německého velvyslance Wolff-Metternicha z 10. července 1916 kancléŕi Theobaldu von Bethmann-Hollwegovi se dochovala obdobná slova:

Přestože je to neustále popíráno, hraje islamizace $\mathrm{v}$ poslední fázi pronásledování Arménů značnou úlohu. [...] V násilné islamizaci Arménů však

24 Michal Řoutil - Petra Koštálová - Petr Novák. Katastrofa krestanů. Likvidace Arménů, Asyŕanů a Řeků v Osmanské ŕiši v letech 1914-1923, s. 262; viz též Ara Sarafian. The Absorption of Armenian Women and Children into Muslim Households as a Structural Component of the Armenian Genocide. In: Omer Bartov - Phyllis Mack (eds.). In God's Name: Genocide and Religion in the Twentieth Century. Oxford: Berghahn Books 2001, s. 209-221.

25 Wolfgang Gust (ed.). Der Völkermord an den Armeniern 1915/16, s. 209. 
nesmíme vidět opatření přijaté pod vlivem náboženského fanatismu. Tyto pocity mladoturečtí mocipáni nesdílejí [...] hlavní pohnutkou není náboženský fanatismus, jako tomu bylo např́klad u násilné konverze Židů a Maurů v 15. a 16. století ve Španělsku. Cílem je promísit (zu amalgamieren) Armény s muslimským obyvatelstvem říše. ${ }^{26}$

Významnou úlohu v poturčení a islamizaci křestanských dětí hrály sirotčince. ${ }^{27}$ Mladoturecká vláda se této otázce začala důsledněji věnovat od dubna 1916, kdy vydala a do provincií rozeslala odpovídající směrnici. ${ }^{28}$ „Ukázkový“ osmanský sirotčinec založil v roce 1916 v libanonském městě Antura (Ajntura) místodržící Sýrie Cemal Paşa. Vedení ústavu se během války na čas ujala také turecká spisovatelka a feministka Halide Edib (Adıvar). ${ }^{29}$ Hlavní ideologický cíl tohoto sirotčince spočíval v poturčení dětí, jejich konverzi k islámu a zařazení do „nové“ osmanské (turecké) společnosti. Dětem byla odebrána jejich rodná jména a nahrazena tureckými, dostaly pořadová čísla, pod hrozbou přísných trestů nesměly mluvit v rodných jazycích.

V sirotčinci pobýval i arménský sirotek z východoanatolské vesnice Gürün (Gurin) Karnig Panian (1910-1989), jenž ve své vzpomínkové knize podrobně popsal chod ústavu. Turecké ošetřovatelky trestaly jakékoliv porušení pravidel včetně rozhovorů v arménštině: „Mluv turecky, drahoušku!“ (Türkçe konuşun güzelim!), napomínaly svěřence. ${ }^{30}$ Brzy po jeho příchodu do ústavu jim ředitelství odebralo arménská jména a přiřadilo turecká. Ředitel školy si pozval pět arménských dětí k pohovoru:

26 Tamtéž, s. 476.

27 Osudům dětí během arménské genocidy je dnes věnována značná pozornost, srov. např. Henry C. Theriault. Hell Is for Children: The Impact of Genocide on Young Armenians and the Consequences for the Target Group as a Whole. In: Samuel Totten (ed.). Plight and Fate of Children During and Following Genocide. New Brunswick, New Jersey: Routledge 2014, s. 29-55; Asya Darbinyan - Rubina Peroomian. Children: The Most Vulnerable Victims of the Armenian Genocide. In: Tamtéž, s. 57-83; a přepracovaná očitá svědectví: Donald E. Miller - Lorna Miller Touryan. Survivors: An Oral History of the Armenian Genocide. Berkeley: University of California Press 1999, s. 94-117. Women and Children, 1915-1916. Études arméniennes contemporaines 7 (2016), s. 80. Asyranů a Řeků v Osmanské ŕiši v letech 1914-1923, s. 235-236.

30 Karnig Panian. Goodbye, Antoura. A memoir of the Armenian genocide. Stanford, California: Stanford University Press 2015, s. 79. 
Začal mluvit nabubřele, rozuměl jsem mu však jen pár slov. Jádro jeho proslovu spočívalo ve sdělení, že máme zapomenout svá současná jména, protože dostaneme jména nová. Tento akt znamená počátek naší proměny v hrdé Turky. Kromě nových jmen nám byla rovněž přidělena čísla. ${ }^{31}$

V sirotčincích, které zakládali a vedli křestanští misionáři či humanitární organizace, k žádným islamizačním a poturčovacím akcím přirozeně nedocházelo. Kupříkladu v sirotčinci, který vedla v Charputu dánská misionářka Marie Jacobsenová (1882-1960), se naopak děti mohly hlásit ke svému náboženství svobodně. ${ }^{32}$

\section{Vorpahavak - nelehký návrat k vlastnímu národu a „víře otců“}

Konverze k islámu během genocidy a války znamenaly pro přeživší arménské obyvatelstvo značný problém. Oficiálně se konvertité mohli z tohoto závazku vyvázat sice až po uzavření mudroského příměří v říjnu 1918, ve skutečnosti však řada z nich tak učinila, jakmile se k tomu naskytla příležitost. V únoru 1919 se do celé věci vložila také vláda. Velkovezír Ahmet İzzet Paşa rozeslal do provincií př́kaz, který dovoloval, aby se osoby mladší dvaceti let, které o to projeví zájem, mohly „vrátit k vlastnímu pravému náboženství" (dîn-i aslilerine rücu). ${ }^{33}$

Ačkoliv opuštění islámu šaríatské právo zakazovalo, většině Arménů s konexemi se opětovná změna víry podařila - přirozeně často díky korupci, tedy podplacení konkrétních osmanských úředníků či muslimských duchovních. Existovala rovněž početná skupina křestanů, kteří nucené přijetí islámu zatajili. V poválečném chaosu stačila změna bydliště či identity, aby se okolí konverze nedopátralo. Arméni, kteří z Osmanské říše (a od roku 1923 Turecka) odešli do některé z blízkovýchodních zemí, Evropy či Spojených států, se k případné konverzi také nehlásili.

Pro komunitu, která v zemi zůstala, se otázka návratu islamizovaných Arménů ke křestanství stala jednou z prioritních, ne-li vůbec nejdů-

\footnotetext{
Tamtéž, s. 80.

32 Maria Jacobsen. Diaries of a Danish Missionary: Harpoot, 1907-1919. Princeton, New Jersey - London: Taderon 2001.

33 Uğur Ümit Üngör. Orphans, Converts, and Prostitutes: Social Consequences of War and Persecution in the Ottoman Empire, 1914-1923. War in History 19, 2 (2012), s. 184.
} 
ležitějších. Po opětovném převzetí svého úřadu se úkolu „vysvobozeni“ (azadakrum) islamizovaných souvěrců věnoval také arménský konstantinopolský patriarcha Zaven Der Jeghiajan (1868-1947). Rozsáhlá akce „shromažd'ování sirotků“ (vorpahavak) probíhala ve všech provinciích, v nichž církvi ještě zůstaly vlastní struktury. Akce se účastnily také arménské a zahraniční organizace a po založení konstantinopolské Agentury pro shromažd'ování sirotků (Vorpahavak marmin) také vybraní „agenti“. ${ }^{34}$ Jen v Konstantinopoli se podařilo zachránit z muslimských domácností na 3000 sirotků z předpokládaných 4000 až 5000 islamizovaných Arménů. Mimo hlavní město však byla daleko menší úspěšnost: „[...] tam jsme mohli osvobodit jen několik málo ze stovek tisíc sirotků. Stalo se tak proto, že po porážce Turecka spojenecké armády nepostupovaly dále do vnitrozemí. “35 Návrat sirotků k víre a do vlastních rodin probíhal - na rozdíl od Anatolie, o níž patriarcha hovoří - již koncem roku 1917 na územích, která dobyli Britové, tedy na Sinaji, v Palestině, Sýrii a části Iráku. ${ }^{36}$

Vorpahavak však zdaleka neprobíhalo bez problémů. Muslimské rodiny - turecké, kurdské, arabské, čerkeské a jiné - často nechtěly své „adoptované“ syny, dcery či manželky Arménům vydávat. Situaci někdy komplikovala neochota samotných islamizovaných Arménů k opuštění muslimských rodin. Zvláště děti, od jejichž „adopce“ uběhlo v průměru 4 až 5 let, si vlastní rodinu často ani nepamatovaly. Nejednou rovněž muslimští příbuzní přísahali, že se jedná o pravé muslimy, nikoliv křestany. V případě chlapců napomáhal v identifikaci fakt, že všichni museli při přijímání nové víry podstoupit u křestanů zcela

34 Více k situaci uprchlíků po 1. světové válce viz in: Raymond Kévorkian - Lévon Nordiguian - Vahé Tachjian. Les Arméniens 1917-1939: la quête d'un refuge. Paris: RMN 2007; Vahram L. Shemmassian. The Reclamation of Captive Armenian Genocide Survivors in Syria and Lebanon at the End of World War I. Journal of the Society for Armenian Studies 15 (2006), s. 113-140; Katharine Derderian. Common Fate. Different Experience: Gender-Specific Aspects of the Armenian Genocide, 1915-1917. Holocaust and Genocide Studies 19 (2005), s. 1-25; Dzovinar Kévonian. Refugiés et diplomatie humanitaire: les acteurs européens et la scène proche-orientale pendent l'entre-deuxguerres. Paris: Publications de la Sorbonne 2004; zajímavé vzpomínky jednoho z agentů-sběratelů dětí viz: Levon Yotnakhparian. The Crows of the Desert: Memoirs of the Levon Yotnakhparian. Tujunga: Parian Photographic Design 2012. Zaven Der Yeghiayan. My Patriarchal Memoirs. Barrington: Mayreni 2002, s. 185. Více viz: Vahé Tachjian - Raymond Kévorkian. Reconstructing the Nation with Women and Children Kidnapped during the Genocide. Ararat 45, 185 (2006), s. 4-16; Vahé Tachjian. Gender, nationalism, exclusion: the reintegration process of female survivors of the Armenian genocide. Nations and Nationalism 15 (2009), s. 62nn. 
vyloučenou obřízku. ${ }^{37}$ Stávalo se, že se obě skupiny vzájemně obviňovaly z únosu a násilné konverze. Osmanský stát se k tématu stavěl spíše vlažně, za což si nejednou vyslechl kritiku od britské okupační správy. ${ }^{38}$

Arménští dobrovolníci pátrající po sirotcích v muslimských domácnostech a sirotčincích po celém Blízkém východě navíc zavedli pravidlo, že každé dítě, narozené prokazatelně arménské matce, je plnohodnotným Arménem, a musí být opětovně „armenizováno“. Tato praxe však byla v příkrém rozporu s dosavadní osmanskou tradicí, kdy se etnicko-náboženská příslušnost vždy určovala podle otce, což platilo jak pro arménské kanonické právo, tak pro muslimskou šaríu. Arménští kněží tak křtili (případně překřtívali) děti, které by v předválečné době prokazatelně patřily do muslimského vládnoucího milletu (millet-i hâkime). Kvůli konfliktům tohoto druhu musela britská okupační správa v Konstantinopoli v roce 1918 dokonce zřídit „neutrální domy“, kam sirotky umistovali, než se vyjasnil jejich původ a náboženství. ${ }^{39}$

Pomoci v rechristianizaci islamizovaných Arménů se snažila také arménská diaspora. Jednalo se o jednu z fází celkové konsolidace národa po genocidě, která již v té době dostala označení „národní znovuzrození“ (azkajin veradznunt) či „národní reorganizace“ (azkajin verašinum / veraganknum).$^{40}$

Zachraňovány „pro budoucnost národa“ a křestanskou víru nebyly jen děti, nýbrž také ženy. Vyvraždění takřka veškeré mužské populace během genocidy zapříčinilo, že se bez mužů či manželů ocitly desítky tisíc dívek a žen. Další desítky tisíc byly násilně provdány a začleněny do muslimských domácností. Značný počet žen si zachránil život také nucenou či dobrovolnou prostitucí.

Tragická situace vyžadovala od tradicionalisticky a paternalisticky založené arménské společnosti značné a do jisté míry před genocidou zcela nepřijatelné morální ústupky. Dříve tolik akcentovaná ženská zbožnost, „nevinnost“, „čistota“ a „bezúhonnost“ nemohla být v situaci, kdy muslimští muži drtivou většinu deportovaných arménských žen znásilnili, hlavním kritériem výběru životní partnerky. Pro mnoho

37 Taner Akçam. A Shameful Act: The Armenian Genocide and the Question of Turkish Responsibility, s. 310.

38 Tamtéž, s. 311.

39 Lerna Ekmekçioğlu. Recovering Armenia: The Limits of Belonging in Post-Genocide Turkey. Stanford: Stanford University Press 2016, s. 34n.

40 Tamtéž, s. 22. 
mužů z diaspory se tak stalo aktem vlastenectví a dílčím krokem k záchraně národa, že pojali za svou některou ze zneuctěných žen. Již ke konci roku 1916 se tak například v bostonských arménských novinách Hajrenik (Vlast) objevovaly inzeráty tohoto znění: „Arménský muž neodmítne ženu, která byla unesena, protože se stala nevinnou obětí a nemůže nést morální zodpovědnost za svůj stav.“41 Tohoto př́stupu se držela také arménská apoštolská církev - konstantinopolský patriarcha opakovaně vybízel muže z diaspory k patrioticky zaměřeným sňatkům s ženami „ovdovělými“ během genocidy; za „čest národa“ dokonce prohlašoval arménské prostitutky, „neštastné sestry“, které zachránil ke konci války v Mosulu, kam byl poslán vládou do vyhnanství.

Narovnáním poválečných sociálních a rodinných vazeb v oblasti Blízkého východu se tehdy několikrát zabývala také nedávno založená Společnost národů. V květnu 1920 mj. apelovala britská feministka a pacifistka Helena L. M. Swanwicková (1864-1939) na tuto organizaci a požadovala aktivní účast Společnosti v této kampani. ${ }^{42}$ Sekretářka arménského Červeného kř́že a britského Fondu pro uprchlíky Emily Robinsonová popsala naléhavost situace:

[...] nespočet tisícovek arménských žen a dětí je dosud drženo v muslimských domácnostech, v nichž žijí v zajetí od roku 1915. Příměří s Tureckem stanovilo, že budou propuštěni všichni váleční vězni. Byli ovšem propušténi pouze muži, k naplnění dohod týkajících se žen nedošlo. [...] Současný stav věcí je nebezpečný a extrémní, a to zvláště v př́padě míru na Východě. Kromě toho je skandální a ostudný pro civilizaci 20. století. ${ }^{43}$

\section{Kryptoarméni a fenomén „skryté armenity“ v současné Anatolii}

Pomyslný předěl nad otázkou islamizovaných arménských žen a dětí po genocidě představoval příchod k moci tureckého Národního hnutí. Po vítězné ofenzivě Mustafy Kemala a ovládnutí země to byli jeho

\footnotetext{
41 Tamtéž, s. 36; viz též Isabel Kaprielian-Churchill. Armenian Refugee Women: The Picture Brides, 1920-1930. Journal of American Ethnic History 12, 3 (1993), s. 3-29.

42 Keith David Watenpaugh. Bread from Stones: The Middle East and the Making of Modern Humanitarianism. Oakland, California: University of California Press 2016, s. $133-134$.

43 Tamtéž.
} 
zástupci, kdo rokovali v Lausanne o budoucím vnitřním uspořádání země. Menšiny v Osmanské říši se dostaly na lausannské konferenci na přetřes v prosinci 1922 a turecká strana odmítala podepsat jakýkoliv paragraf budoucí smlouvy, v němž by se hovořilo jak o reparacích, tak o vyhledávání a návratu křestanských žen a dětí do domovského prostředí. Podle tureckého delegáta Rızy Nury se jednalo o problém, který „zůstal v minulosti““. ${ }^{44}$ Neměl ovšem tak úplně pravdu.

S tím, jak se kemalistické Turecko snažilo zcela politicky, společensky i kulturně odtrhnout od osmanské minulosti, považovalo také některé bolestivé otázky za uzavřené. Právě proto zůstávali turečtí Kryptoarméni (tur. Gizli, resp. Kripto Ermeniler, arm. Cptjal hajer) až do nedávna prakticky zcela neznámým fenoménem. ${ }^{45}$ Jedná se o dnešní turecké občany, kteří zjistili, že jejich prarodiče patřili k arménskému národu, nicméně dobrovolně či pod nátlakem přijali islám. V současném Turecku žije asi 30 až 40 tisíc Kryptoarménů, ale jejich potomků může být podle některých současných autorů až na dva miliony. ${ }^{46}$ Zdá se tedy, že v tureckých, kurdských a arabských rodinách Anatolie a severní Mezopotámie přetrvává jistá vzpomínka na arménskou minulost. ${ }^{47}$ Tito lidé však musejí stále vypracovávat různé postupy a strategie, jak se vyrovnat s konfuzností vlastní identity i s většinovou muslimskou společností. ${ }^{48}$

Na počátku vlny zájmu o tyto „skryté“ Armény se stalo vydání autobiografického př́běhu Má babička istanbulské právničky Fethiye Çetinové - o arménském původu své babičky se dozvěděla až na sklonku jejího života a pokusila se společně s ní rekonstruovat rodinnou

44 Taner Akçam. A Shameful Act: The Armenian Genocide and the Question of Turkish Responsibility, s. 313; srov. též Ayşe Gül Altınay - Yektan Türkyilmaz. Unravelling layers of gendered silencing: Converted Armenian survivors of the 1915 catastrophe. In: Amy Singer - Christoph K. Neumann - Selçuk Akşin Somel (eds.). Untold Histories of the Middle East: Recovering Voices from the 19th and 20th Centuries. London - New York: Routledge 2011, s. 25-53.

45 K otázce kryptokřestanů v Osmanské říši před rokem 1914 srov. Selim Deringil. Conversion and Apostasy in the Late Ottoman Empire, s. 111-155.

46 M. Freeley. Preface. In: Fethiye Çetin. My Grandmother: An Armenian-Turkish Memoir. London - Brooklyn: Verso 2008, s. ix.

47 Několik případů viz Guillaume Perrier - Laure Marchand. Turkey and the Armenian Ghost: On the Trail of the Genocide. Montreal \& Kingston - London - Ithaca: McGill-Queen's University Press 2015, s. 35-58.

48 Viz např. Uğur Ümit Üngör. Conversion et sauvetage. Stratégies de survie au cours du génocide des arméniens. In: Jasques Sémelin - Claire Andrieu - Sarah Gensburgers (eds.). La résistance aux génocides. De la pluralité des actes de sauvetage. Paris: Presses de Sciences 2008, s. 221-233. 
mikrohistorii. Knize se dostalo značného ohlasu v tureckém a arménském prostředí, ale také v zahraničí. Později Çetinová sestavila společně s Ayşe Gül Altınayovou knihu Vnoučata, která shrnuje svědectví vnoučat a pravnoučat islamizovaných Arménů. ${ }^{49}$ Skryté Armény na různých místech dnešního Turecka vyhledával také spisovatel Kemal Yalçin. Výsledkem se stala kniha Rozveselil jsi mé srdce. ${ }^{50}$

Po otevření této otázky začaly desítky občanů Turecka pátrat po své „skryté armenitě“. V oblasti Dersimu (leží v provinciích Tunceli, Elazığ a Bingöl) se k arménskému původu přihlásilo již více než 200 rodin, z nichž některé se rozhodly konvertovat zpět ke křestanství. Podle Mihrana Gültekina, zakladatele „Sdružení dersimských Arménů“, má až 75 procent obyvatel z této oblasti částečně arménské kořeny. ${ }^{51}$

V tureckém prostředí bývají Kryptoarméni někdy označováni jako „pozůstatky meče“ (kılıç artı̆̆l); v obecném povědomí jsou pak konvertité $\mathrm{k}$ islámu, někdy i dlouho po aktu samém, označováni za dönme, tedy „obrátilce“. Politická nestabilita po 1 . světové válce a strach z dalšího pronásledování způsobily, že se mnoho někdejších křestanů už ke své původní víře nepřihlásilo. ${ }^{52}$ Někteří tak sice učinili později, ale museli se odstěhovat do Istanbulu, nebo dokonce odejít ze země. ${ }^{53}$

Pro většinu Arménů v diaspoře i v Arménské republice byla otázka konvertitů ještě donedávna tabuizovaným tématem, protože by jejich př́tomnost ve východní Anatolii mohla posloužit jako argument odpůrců arménské genocidy. Arménština označuje tyto konvertity slovy thakhun Hajer („tajní“, „skrytí Arméni“), merinner („našinci“), dardzac („obrátilci“, „konvertité") nebo také kes-kes (tj. „půl-půl“). Muslimští Arméni svou identitu tajili někdy tak dlouho, že ji sami považovali za cosi vzdáleného a v muslimském prostředí, kde žili,

49 Ayşe Gül Altınay - Fethiye Çetin. Torunlar [Vnoučata], İstanbul: Metis Yayınları 2011; Ayşe Gül Altınay - Fethiye Çetin. The Grandchildren: The Hidden Legacy of 'Lost' Armenians in Turkey. New Brunswick, New Jersey: Routledge 2014.

51 Dostupné z: <https://massispost.com/2011/02/mihran-gultekin-dersim-armenians -re-discovering-their-ancestral-roots $>$ (22.11.2017).

52 Maurus Reinkowski. Hidden Believers, Hidden Apostases: The Phenomenon of Crypto-Jews and Crypto-Christians in the Middle East. In: Dennis Washburn - A. Kevin Reinhart (eds.). Converting Cultures: Religion, Ideology, and Transformations of Modernity. Leiden: Brill 2007, s. 409-433.

53 Př́́klad návratu islamizovaných Arménů ke křestanství z 50. letech 20. století viz in: Talin Suciyan. The Armenians in Modern Turkey: Post-Genocide Society, Politics and History. London - New York: I. B. Tauris 2016, s. 53. 
za něco nepatřičného. V některých muslimských komunitách však dosud nejsou považováni za „správné“ muslimy, protože jejich konverze neproběhly vždy řádně podle šaríi. Ve východní Anatolii tak mají daleko blíže k alevitským Kurdům než k sunnitským Turkům. ${ }^{54}$

Arménský spisovatel Aram Haigaz, z jehož díla jsme vybrali motto tohoto článku, genocidu na rozdíl od většiny členů své rodiny přežil. Po „dobrovolné“ konverzi se čtyři roky ukrýval mezi muslimy v kurdských horách. Přechod k islámu pro něj ovšem neznamenal ztrátu armenity, k níž neodmyslitelně patří i křestanství. Uposlechl sice matčina př́ikazu, aby se pro záchranu života vzdal původního náboženství, avšak jako desetitisíce jiných se k „víře otcü“ vrátil okamžitě, jakmile to situace dovolovala.

Filozofická fakulta

Univerzita Hradec Králové námèstí Svobody 331

Hradec Králové

E-mail: michalrout@post.cz

${ }^{54}$ K alevitům viz Kateřina Vytejčková. Alevité. In: Jiří Gebelt a kol. Ve stínu islámu. Menšinová náboženství na Blízkém východé, s. 257-290. 